\title{
Islamic Schools, the Ulama, and the State in the Educational Development of Northern Nigeria
}

Nasir Mohammed Baba

\section{(e) OpenEdition \\ Journals}

Electronic version

URL: http://journals.openedition.org/apad/4092

DOI: 10.4000/apad.4092

ISSN: 1950-6929

Publisher

LIT Verlag

\section{Printed version}

Date of publication: 1 August 2011

\section{Electronic reference}

Nasir Mohammed Baba, «Islamic Schools, the Ulama, and the State in the Educational Development of Northern Nigeria », Bulletin de l'APAD [Online], 33 | 2011, Online since 22 March 2012, connection on 07 September 2020. URL : http://journals.openedition.org/apad/4092 ; DOI : https://doi.org/10.4000/ apad.4092

This text was automatically generated on 7 September 2020 .

Bulletin de l'APAD 


\title{
Islamic Schools, the Ulama, and the State in the Educational Development of Northern Nigeria
}

\author{
Nasir Mohammed Baba
}

\section{Introduction}

1 Nigeria has a large concentration of children who are not attending school despite a decade of investment in a programme of mass education, the Universal Basic Education (UBE), launched in September 1999. The Federal Ministry of Education (FME 2009) admits that 10.5 million children (or $30 \%$ of the primary school-age cohort) do not have access to primary education, but this figure masks widespread disparities between the nation's six geopolitical zones. For instance, in the North-East and North-West zones, commonly referred to as the 'core north', over $50 \%$ of the children do not attend school compared with less than $20 \%$ in the South-East and South-South (National Population Commission, NPC, \& IFC Macro 2009). The core north has a predominantly Muslim population and its long history of contact with Islam shaped its socio-economic and political framework long before colonisation by the British. Therefore, the introduction of Christianity, western education and colonial state structures by missionaries and colonialists threatened an established social order that derived legitimacy from its linkages with Islam. The public school system, erected by the colonial state and sustained by the post-colonial elite, had to contend with a persistent religious parallel in the form of Islamic schools. A continuous concern in the discourse on education in Northern Nigeria has been how to mitigate the influence of these schools on popular participation in state-sponsored education programmes.

2 By exploring their past interactions with pre-colonial, colonial and post-colonial state structures in Nigeria, this discourse seeks to establish that little has changed in the essential character of Islamic schools as a loose network of schools under the direction of their individual patrons. This has given the schools a certain degree of fluidity that 
makes their interactions with Nigeria's public education difficult, and limits their contributions to the policy goal of universal access to education. It has also conferred on individual members of the ulama $a^{1}$ the unregulated power to define the intellectual direction of the schools they own and the scope of their interaction with the state. The paper examines three variants of Islamic schools (Islamiyya, Madrassa and Traditional Qur'anic Schools) that have evolved among Hausa people in the core north. The aim is to analyse the complex pattern of co-operation, competition and avoidance that characterises the relationship between the ulama and the state in the educational arena. $^{2}$

\section{The State, Ulama and Education in Nigeria}

3 The most distinctive feature that defines the ulama is their expertise in, and preoccupation with, religious, educational and legal affairs that constitute the broad ideological parameters of Islamic societies (Umar 2006). Historically, being a member of the ulama establishment entailed full-time engagement with matters of scholarship and piety (learning, teaching and preaching) that left little or no time for generating an income. The lack of regular income therefore made the ulama reliant on the goodwill and support of the Muslim community or an influential patron. Assurance of this support appears to have been a necessary condition for the development of the ulama class in Hausa communities in pre-colonial Northern Nigeria (Balogun 1980). Therefore, when a Muslim cleric arrived in an area, a mutually beneficial alliance was naturally struck between him and the ruling elite leading to the gradual integration of the ulama into the ruling elite in these areas. In return for the necessary permission, material comforts and assurances of personal safety and protection from their benefactors, the ulama deployed their mystic power, literacy skills and religious and judicial knowledge in the service of the state or influential members of the political establishment (Balogun 1980). This symbiosis between the ulama and the political class gave Islam and Islamic education the necessary footholds in Northern Nigerian cities and towns that subsequently became well-known for Islamic scholarship at different times. Scholars like Muhammadu Al-Maghili were known to have laid the framework for the establishment of Islamic legal and administrative systems in Kano and Katsina through their alliances with the political leadership in these areas (Clarke 1982). In Katsina, AlMaghili also established an institution of learning at Gobarau that became a prominent centre of Islamic learning (Bugaje 1997). There were, however, less-celebrated instances of the ulama that blended into the political reality of the Hausa states by condoning the mixture of Islam with prevailing un-Islamic local customs and traditions. Irrespective of the roles they played, the point of emphasis is that, by the $18^{\text {th }}$ century, the ulama had occupied positions of authority in the local politicl structures that enabled them to influence state policy and programmes.

4 However, the linkages the ulama developed with the political class did not succeed in placing education on the development agenda of the state (Khalid 1999). Therefore while some Islamic influence could be felt in the legal and administrative structures of some Hausa states (even if only nominally), education still remained on the fringe of state policy. The main reason for this may have been little demand for education among the populace. By the $18^{\text {th }}$ century, there were strong allegiances with traditional religions among the local populace in Hausa states, even in political enclaves headed by 
Muslim rulers. For instance, the Kings of Kano and Katsina, although Muslim themselves, ruled over territories where the population was largely non-Muslim (Clarke 1982). As a result, governance structures in these states had to be a compromise between traditional religio-political systems and Islamic governmental principles and practice. Another reason for the failure to evolve a state policy on education may have been political instability. The frequent in-fighting that characterised relationships between the Hausa states of Zamfara, Gobir, Katsina, Kano, and Kebbi for much of the $18^{\text {th }}$ century meant that none of them enjoyed the lasting tranquillity needed to pay serious attention to education.

5 It was therefore left to the ulama in their role as scholars, teachers, and preachers to spread Islamic education beyond the confines of rulers' courts and the cities to various locations in the Hausa states. By the beginning of the $19^{\text {th }}$ century, Islamic education had spread and developed clear patterns and well-established curricula through the efforts of individual members of the ulama (Abdulrahman \& Canham 1978). This not only increased the number of Islamic adherents among the masses but also led to the growth of ulama within the ranks that had no linkages with the political class. In choosing to distance themselves from power and corruption, these scholars were following in the tradition of the ulama'ul sunna (righteous scholars) who were widely respected as beacons of justice, humility and courage (Bugaje 1997). The ulamaúl sunna tended to be more vocal in their attacks on non-Islamic customs and traditions that were hitherto condoned by the ulama of the royal courts (Balogun 1980). These criticisms provoked tension between the ulamaúl sunna and those ulama (called ulamaúl su' or venal scholars) who served in and sustained governments of unjust Muslim rulers contrary to the provision of the Sharia. Thus by turning against the state (instead of merely coexisting with it), ulamaúl sunna and their disciples created for themselves new spheres of religious authority beyond the royal courts.

6 The account above suggests that the ulama are not a monolithic body. They have been historically divided on various points of religious belief, practice and politics. But it is their involvement with the ruling elite that appears to have polarised them into opposing political orientations (Umar 2006). According to two prominent ideological torch bearers of the ulamaúl sunna (Al-Maghili and Sheikh Usman Danfodio), before a malam could undertake the functions of the ulama, he requires a thorough understanding of the writings of respected orthodox scholars. He also needs independence of thought unencumbered by any materialism or allegiance to a political authority. By aligning themselves to political power, the ulamaúl su' were considered to have compromised these vital scholarly credentials. Sharing in the discredit of ulama'ul su' were the lesser or pseudo scholars (Gardawa) who, on account of their limited learning, are technically not members of the ulama. However, despite their limited learning, Gardawa perform all the functions of the ulama outlined above, including establishing schools and preaching in rural areas beyond the scrutiny of more established scholars (Clarke 1982). Attacks on the activities of these scholars and teachers were to form part of the basis of the Danfodiyo-led Jihad at the beginning of the $19^{\text {th }}$ century.

7 An ulama-led Jihad (Sokoto Jihad of 1804) was the outcome of the stand-off between the ulamaúl sunna and the ruling elite (including their advisers from the ulama class) that sought to cleanse Islam of customs and traditions considered un-Islamic. The successful execution of this Jihad led to the founding of an Islamic empire (the Sokoto Caliphate) 
that eventually displaced the traditional ruling elite from positions of power and reduced the political influence of the ulamaúl su. By placing them in positions of political power, the Jihad provided the ulamaúl sunna (the erstwhile opponents of ulama-state engagements), the instrument of state to translate their religious agenda into concrete programmes. It is worth remembering that while the ulama made an immense individual contribution to the growth of Islamic education, bringing the machinery of state to the side of education eluded them for too long.

Unfortunately, even the Jihad did not change this pattern because education did not feature prominently as a state programme even after the establishment of the caliphate (Ardo \& Junaid 1990). While in their individual roles as scholars, leaders of the Jihad strengthened the existing pattern of Islamic education by producing a large collection of books and poems, there is little evidence to suggest a deliberate effort by the state to take over education and implement a programme (Abdulrahman \& Canham 1978). Although one may be tempted to attribute this to a lack of a centralised control over the caliphate's confederate states, the existence of an administrative structure of 21 departments at the centre weakens this argument. The central government may not have had direct control over the more than 36 emirates in the caliphate, but it served to be an administrative model from which the emirates copied. However of the 21 departments established by the caliphate for state administration, none was in charge of education. ${ }^{3}$ As a result, the model of education established since the $14^{\text {th }}$ century based on the study of jurisprudence, theology, mysticism, grammar, rhetoric and exegesis remained largely unchanged long after the establishment of the caliphate, and even to the present day (Ardo \& Junaid 1990). By the beginning of the $20^{\text {th }}$ century when the British colonialists conquered and established their suzerainty over the caliphate, Islamic education was very much alive in the hands of the ulama. However, the system was dealt a heavy blow even before the formal commencement of colonialism due to the death or dispersal of a large number of ulama in the military campaigns that characterised British colonial conquest of the Sokoto caliphate (Khalid 1997). In addition, by introducing an alternative education and making its acquisition the sole criterion for entry into privileged positions, the 'new' colonial order undermined the monopoly of the Ulama over literacy and access to positions, resources and prestige (Umar 2001). Overwhelmed but not dead, Islamic schools persisted as parallels to the growing dominance of western education. Lacking any cohesive response to the onslaught of western education and modernity, these schools maintained an exclusive focus on other-worldly aspects of Islamic education described earlier (Bano 2009). Even though Islamic schools continued to have large patronage among the populace, they remained without supervision or support from the state because the British colonial authorities failed to develop a coherent policy of engaging with them or their owners. Instead, the attitude of the colonialists towards these schools were characterised by ambivalence, and neglect (Abdulrahman \& Canham 1978; Ozigi \& Ocho 1981). Therefore, while the ulama lost linkages with the state, their control over curricula contents, instructional practices and management of Islamic schools remained as it had always been in the pre-colonial period: uncontested and unchecked.

9 The post-colonial state that emerged after Nigeria's independence in 1960 made concerted efforts to expand western education as a strategy for confronting the development challenges facing an emerging nation-state. The Northern Region, which comprised states in present-day Northern Nigeria, had the largest concentration of 
Islamic schools but was lagging behind the other regions in terms of 'official' educational development. For instance, at independence, Northern Nigeria (with over half of the country's population) accounted for less than $10 \%$ of primary-school enrolment and less than 5\% at secondary-school level (Dudley 1968). The spate of educational expansion that the region witnessed in response to this educational imbalance proceeded on a similar pattern of limited engagement with Islamic schools followed by their complete abandonment by the state in subsequent years. Using his charismatic influence and control over state resources, the Premier of the Northern Region, the late Sir Ahmadu Bello, initiated plans to put in place a programme for the gradual reform and state support of local Islamic institutions (Khalid 1997; Odumosu, Olaniyi \& Alonge 2009). The impact of this policy thrust was the provision of state support to those Islamic schools willing to modernise, as well as the establishment of a limited number of state schools meant for the training of teachers that would cover the Arabic language and Islamic education components on the curricula of formal schools. However, the assassination of the Premier in 1966 led to a reduced tempo in the implementation of these programmes and robbed Islamic schools of a strong pillar of support within the state bureaucracy. Moreover, the dismantling of regional administrative structures across the country and their replacement with smaller semiautonomous administrative units or states, which began in $1967,{ }^{4}$ made it harder for states in Northern Nigeria to develop a common regional response to a problem that is peculiar to them. The prolonged absence of a common policy framework for dealing with Islamic schools facilitated the continuation of ambivalent relationships and occasional engagements, mutual isolation and neglect between the various state governments in Northern Nigeria and Islamic schools that dates back to the colonial era. While the devastating consequences of this isolation and neglect on Islamic schools, their pupils and owners became obvious, the long-term implications of these developments on the stability of the Nigerian state took longer to manifest themselves.

\section{State-Sponsored Education, Failed Promises and the Resurgence of Nigerian Madrassas}

10 The 1970s were characterised by a flurry of development activities in Nigeria, motivated by increased revenue and the demands of post-war reconstruction after the termination of the country's civil war in 1970. One of the most significant developments in the education sector was the promulgation of a new National Policy on Education (NPE) in 1977 following the recommendations of a national curriculum conference held in 1969. The NPE had been preceded in 1976 by the launch of an ambitious programme of mass education, the Universal Primary Education (UPE) programme, aimed at providing free and universal access to primary education to all school-aged children (Taiwo 1980). The Federal Government of Nigeria (FGN), according to Taiwo, introduced UPE, convinced that only a programme of such a scale could address the problem of educational imbalance between the north and the south of the country. In addition, it was also hoped that the UPE would facilitate the realisation of the vision of a new Nigeria.

11 Emboldened by an attractive revenue profile due to a sudden rise in the price of petroleum in 1973, the FGN took on the responsibility of providing all the funds for the implementation of the UPE, while state governments would act as implementing agents 
(Taiwo 1980). Prior to the implementation of the UPE, the FGN had assumed exclusive responsibility for the provision and funding of all aspects of higher education in 1972 (Taiwo 1980). It also took over the management of all missionary and private schools to meet the public's increasing demand for education (Umar 2003). Consequently, budgetary allocation for education rose from $\mathrm{N} 282 \mathrm{~m}$ in the Second National Development Plan (1970-1974) to N3.1bn in the Third NDP (1975-1980) (Umar 2003). These measures, according to Umar, represented the expansion of the developmental state in the education arena. In the first year alone, school enrolments in many states went beyond official projections (Taiwo 1980). Even in the Muslim-majority states of Northern Nigeria (such as Kano and Sokoto) known for their apathy to western education, school enrolments rose significantly (Khalid 1997) but were still below official projections (Aiyepeku 1989). According to Umar (2003), the growing prosperity of the oil-boom years and the prospects of tangible material rewards for acquiring western education helped to neutralise Muslims' hostility towards it.

12 The overwhelming success of the UPE in terms of the quantitative expansion of school enrolment was to be its undoing. Large pupil enrolments placed a heavy toll on teachers, classrooms, school furniture and the supply of books. It soon emerged that the implementation of the programme had been done without adequate planning (Taiwo 1980). Dwindling revenues due to the fall in petroleum prices in the early 1980 s meant a decline in the state financing of education. Debt relief and the Structural Adjustment Programmes (SAPs) that followed the post-oil-boom years in oil-exporting countries had the consequence of undermining the credibility of the state and ruling elite in these countries as was reflected in their inability to deliver on previously established levels of social services that constituted the social compact with their subjects (Lubeck 1999). Reduced state financing of education in Nigeria meant that parents had to bear a substantial burden of the financing of their children's education, even at a level (primary education) that the state promised would be free. In 2003 when the Universal Basic Education Commission (UBEC) carried out a national assessment of learning achievements in Nigeria's public schools, $80 \%$ of the schools lacked basic school infrastructure (adequate classrooms, school furniture, and chalkboards), while $60 \%$ lacked curriculum modules and textbooks (Adekola 2007). The failed implementation of the UPE has affected the delivery of public education in Nigeria in ways it is yet to recover from. But more importantly within the context of this discussion, it has damaged public confidence in state-sponsored education and the credibility of formal institutions established for its delivery.

13 The cumulative effect of the neglect of public schools was a decline in the performance of pupils in basic literacy and numeracy skills as measured in two assessments of Primary Four pupils in Nigeria's public schools in 1997 and 2003. The mean scores for literacy were 25 and 35 for 1996 and 1997 respectively, while the mean scores for numeracy were 32 and 34 for the same period (Adekola 2007). For parents, a clear measure of quality was whether their children can read, write and perform the basic mathematical operations that were assessed on in the learning achievements reported above. Faced with rather grim prospects for their children's education, parents (Muslims or non-Muslim) are most likely to look for alternative ways of educating their children. The prevalence of private schools and the increase in their patronage by large sections of Nigerian society from the mid-1980s onwards (Umar 2003) attest to growing dissatisfaction with the delivery of public education. The irony in the Nigerian elite enrolling their children in private schools even when they have statutory 
responsibilities to oversee the provision of public education is keenly debated in contemporary Nigerian media. Studies by both USAID (2003a) and Abd-el-Khalik, Boyle \& Pier (2006) suggest that the motivation of parents in enrolling their children in Islamic schools is not entirely religious; they have concerns over quality as well. The point here is to establish the poor delivery of public education in Nigeria as the driving force behind the different manifestations of Islamic schools in the education arena. Although they have been effectively sidelined in the implementation of the state's development agenda in education, Islamic schools have regained relevance following the failure of these developmental policies. Another point that has also been made is the inability of the state to seize the initiative by providing a common framework that would guide the future direction of Islamic schools and establish credible points of contact between these schools and the state-driven education agenda. This situation leaves the ulama in charge of the dominant discourse as far as the participation of Islamic schools in educational development is concerned.

\section{Filling the Gaps: The Nigerian Ulama in the Education Arena}

The gradual deterioration of Nigeria's public education system made it easy for the Ulama and their schools to regain relevance as credible alternatives to the failed policies of the Nigerian sate. Debiel \& Lambach (2010) maintain that in a situation of crisis of state failure, local elites have a way of positioning themselves as 'functional equivalents' by serving as hybrid providers of those public goods that the state does not provide or only provides poorly. They do so by capitalising on some aspects of the state-building agenda to advance their political and economic interests. The model that the ulama in Northern Nigeria capitalised on to register a significant presence in the country's education arena was an institution called the Northern Provinces Law School (NPLS). NPLS was established by the British colonial authority in 1934 to train judges to administer Islamic law in its territories (Umar 2003). Although the school underwent changes in its name, structure and curricula in subsequent years, the possibility it provided of a synthesis between western education and Islamic education was not lost on the Ulama. The pioneering work of Muslim organisations had already established similar models at the primary and post-primary levels among the Yoruba Muslims of South-West Nigeria (Taiwo 1980; Ibrahim 2005). However, even before the Ulama became actively involved, state governments in Northern Nigeria had capitalized on the initiative to establish colleges that offered a combination of western and Islamic education for the training of Arabic teachers, as mentioned earlier. According to Umar (2003), these colleges had become established in the Northern Nigerian cities of Sokoto, Gombe, Maiduguri, Hadejia and Kano by 1979.

By the late 1980s when concerns over the quality of public schools became widespread, the penetration of the Ulama in the delivery mechanisms of public education had, therefore, produced two tracks of Islamic schools that became popular, particularly among urban Muslims in Northern Nigeria. The two types that emerged were those operating the madrassa curriculum and those providing the modified national curricula of public schools (Umar 2003). In addition to incorporating elements of western education in their programmes, both also adopted modern organisational and management styles of public schools. However, they differ from the latter in their 
conscious projection of distinct Islamic cultural identity and orientation in the physical outlay of the school, dress and discipline. Umar reasons that it is the emphasis they place on Arabic and Islamic studies in their curricula that shapes their Islamic character and differentiates them from public schools. The two schools are linked to the educational bureaucracy of the Nigerian state because they operate under the supervision of an agency of government, the National Board for Arabic and Islamic Studies.

By structuring their curricula to reflect the two-tier structure of Nigerian secondary school system, ${ }^{5}$ Islamic schools operating the modified national curricula facilitate the integration of their students in educational and career opportunities without abandoning their pursuit of Islamic education. They have been able to achieve this by broad coverage of subjects prescribed for secondary schools in the NPE, the use of English as the medium for teaching these secular subjects, and putting their students forward for common national examination and certification processes. Although they face constraints that limit their internal efficiencies (Umar 2003; Abd-el-Khalik et al. 2006), these Islamic schools proceed in a direction that reinforces the attainment by the state of common policy goals which are critical to the enthronement of national unity.

The madrassa curriculum, on the other hand, offers exposure to a classical Arabic and Islamic education and provides only limited space for a secular content and the use of English as an instructional or communicative medium. In his analysis of the curricula content of these schools, Tikumah (2008) notes that out of the 12 subjects on the curriculum, 9 focused on the study of Islamic theology, jurisprudence and Arabic. The 4 remaining subjects, apart from carrying less weight on the curricula, are the only subjects taught in English. English is not only the instructional medium in Nigerian schools from the fourth year of primary education (Federal Republic of Nigeria, FRN 2004) but is also the lingua franca for a diverse population with over 250 languages. As far as linkages with public education are concerned, the use of Arabic as an instructional medium in madrassas restricts contact with the broad curricula on offer by Nigeria's higher institutions of learning. While madrassas provide their students with formal qualifications that allow access to higher education, their presence is largely felt in Arabic, Islamic legal studies, and Islamic studies courses. The latest addition to this list is the Nigeria Certificate in Education (NCE) ${ }^{6}$ Arabic Medium programme that has been designed to enable products of madrassas to obtain nationally approved professional teacher training for the teaching of Arabic and Islamic studies. The NCE Arabic Medium programme substitutes English with Arabic as an instructional medium for the teaching of core professional teacher education courses that form part of the NCE programme run in Colleges of Education (COEs) in Nigeria. This is in addition to their study of Arabic and Islamic studies as teaching subjects using the same medium of instruction. General Studies and General English (collectively called GSE courses) are the only components of the NCE Arabic-medium programme that are taught in English. Therefore, although madrassas may be said to have modernised the contents and delivery practices of the old Islamic schools from the pre-colonial era, they have only limited engagement with the national curricula or instructional medium, particularly at the secondary and post-secondary school levels. This limitation also reflects in the overall integration of madrassa students in the national discourse and action in the political, economic or social spheres. 

shoots of Ulama's engagement with western education and the Nigerian public-school system, there is also a third track, which can better be described as the product of a 'fallout' of some ulama with forces of modernity. These are the Traditional Qur'anic Schools (TQS). Their characterisation as 'traditional' is not to suggest that they are indigenous to communities in Nigeria but is used to describe their retention of many of their prototype features since being introduced in Northern Nigeria in the $14^{\text {th }}$ century. The primary function of Qur'anic schools is to contribute to the early upbringing of Muslim children by training them in the reading and memorisation of the Qur'an. In performing these functions, Qur'anic schools laid the foundation for the emergence of an Islamic system of education long before the advent of western education in Northern Nigeria (Clarke 1982). Known in Hausa as Makarantar Allo, Qur'anic school is the first of the two phases that Islamic education typically consists of; the other being Makarantar Ilmi or school for advanced learning. While Qur'anic schools provide the equivalent of modern pre-primary and primary education, Makarantar ilmi is a long educational experience designed to provide students of Qur'anic schools with an understanding of the meaning of the Quran and exposure to other specialised branches of Islamic learning (Fafunwa 1991). Although many of the Islamic schools described above had humble beginnings as Qur'anic schools, the expansion they have witnessed has been concentrated at the advanced level of Islamic learning. In other words, the lower level of Qur'anic schooling has not witnessed the same degree of modernisation and reform as the advanced level.

Unlike the Ulama of the two school types above that are willing to engage with the state and forces of modernity, Qur'anic school proprietors/teachers (malammai in Hausa) prefer to preserve what they perceive as the pristine purity of Islam from contamination by the forces of modernity symbolised by the state. The influence of Christian missionaries in the introduction and propagation of western education in Nigeria helped to reinforce the uncompromising stance of these ulama on contact with or coexistence between Islamic education and western education. Consequently, these schools maintained a tradition of exclusive focus on Qur'anic reading and memorisation as the content of study. While the search for an alternative to a discredited public school system led the modernist ulama and their urban elite followers to the new Islamic schools and madrassas described above, poverty and limited access to these schools have left the urban poor and the rural Muslim populace with no option but Traditional Qur'anic Schools (TQS) to educate their children. Therefore, by the late 1990s, Qur'anic schools commanded more pupil enrolments than formal primary schools in many Northern Nigerian states (USAID 2003b). Given the persistent low primary-school enrolment in states with high incidences of Qur'anic schools reported earlier, there is little reason to believe that the situation has changed in recent times.

Like all other Islamic schools, TQS have suffered from neglect by the state. However, these schools have suffered even more because they lack the internal dynamism to push for change from within, as was the case with the more advanced Islamic schools described above. They have also had a long history of aversion to externally induced change. It is this contradictory reality of the TQS that informed the floating of an integration programme for the TQS by the Federal Government of Nigeria (FGN). The thrust of the programme is to integrate the content from formal school curricula into 
the programmes of these schools without interfering with their traditional mandate or altering their management or control structures (FGN 1999). The FGN hopes that through this programme of reforms, Qur'anic schools will be better empowered for integration into the UBE programme as delivery mechanisms for basic education to a number of children who have been deprived and isolated. However, after about 5 years of implementation, the FGN has conceded that the programme is characterised by many gaps in implementation. These include a lack of engagement with critical stakeholders (the ulama), inadequate supervision and linkages with state educational bureaucracy, poor delivery of instructional facilities/materials, and insensitivity to the needs of the intended beneficiaries of the programme (Federal Ministry of Education, FME 2005). The implementation of this programme is unfolding and a comprehensive review of its progress is yet to be made but if experiences in the formal education sector are anything to go by, implementation infidelity on the part of the state usually creates an ambivalence that local elite (in this case the ulama) capitalise on to promote their own interests. This is particularly the case since local power holders are not employees of the state and are not beholden to it. Instead the state is often seen as an intruder that has to be kept at a distance or eventually bypassed (Debiel \& Lambach 2010).

\section{Implications for Educational Development in Northern Nigeria}

One of the development challenges Nigeria faces in contemporary times is how to harness its many diversities into potential strengths. These ethnic, linguistic and religious diversities are a constant source of tension in the political, social and economic relationships between its constituent parts. With a population of almost 150 million people roughly divided between Muslims and Christians, religion often reinforces regional and ethnic divisions. This heightens communal competition for the country's rich but hopelessly mismanaged human and natural resources. Regional disparities are further compounded by a wide educational imbalance between the largely Muslim north and the predominantly Christian south. These gaps often lead to claims of inequity in the distribution of opportunities requiring formal qualifications. Since the first decade of independence, the country's ruling elite hoped that the expansion of equal educational opportunities would form the basis for national cohesion. Public education, it was hoped, would achieve this by providing a common language and cultural experience and shared values to a new generation of Nigerians whose future decisions would affect the country's destiny (Abernethy 1969). Although the country has since had its NPE and two national programmes of universal access to education (UPE \& UBE), the role of education in national cohesion is beset with many challenges.

Among the challenges of educational delivery, particularly in Northern Nigeria, are the conflicting roles of different varieties of Islamic schools, an Ulama class that does not necessarily share in the national ideals and a state bureaucracy that is not committed to the their pursuit. A section of the ulama and the schools they control has demonstrated a willingness to engage with the state and modern infrastructure of educational delivery in order to advance their participation in education. With this strategy, they have effectively increased their relevance as legitimate institutions for 
furthering the developmental goals of the Nigerian state. In practical terms, they have widened access to educational opportunities and the accruing mobility prospects to a large number of Muslim youth (including women) in a culturally sensitive setting. However, by positioning themselves as 'functional equivalents' to the state in the provision of vital social services such as education, these modernist ulama are also seeking to enthrone Islamic values into the largely secular, western-oriented bureaucracy and knowledge structure of Nigeria's public schools (Umar 2001). In this context, the failure of the state to fulfil its development and welfare rhetoric (what Nigerians call 'dividends of democracy') is often projected as evidence of the sterility of western ideas, thoughts and practices. Islamism, as the doctrine of the modernist Ulama is called, represents an alternative political discourse that challenges western hegemony even as it engages with its global infrastructure, strategies and institutions (Lubeck 1999). The new Islamic schools of the modernist ulama are therefore producing a young cadre of Muslim men and women who are not only capable of engaging in the dominant national discourse but also of redirecting it in line with their religious values and teachings.

While some Ulama seek engagement with the state and its modern structures, others prefer to maintain a distance in the hope that doing so will help them preserve the teachings and ideals of Islam. By operating exclusively religious schools that are neither recognised by nor linked to state educational bureaucracy, these ulama isolate the large number of school-age children they enrol from the modern infrastructure of polity and economy. Therefore, the large numbers of pupils reportedly 'out of school' are enrolled in these TQS. Since neither the state nor communities provide for the welfare needs of these children, they suffer social dislocation and economic deprivation. Growing into an adult life of exclusion and limited opportunities, products of these schools have in recent times been associated with socio-religious upheavals executed under the spiritual direction of some members of the Ulama. These traditional religious schools have also provided the intellectual and recruitment base for what Danfulani (2009) refers to as 'syncretistic and anti-establishment' Islamic movements. These movements blend Hausa folk beliefs and practices with selected parts of Qur'anic content to justify anti-development practices such as non-school enrolment, the rejection of immunisation programmes, and the denial of women's and children's rights. The latest manifestations of these movements are the Boko-Haram ${ }^{7}$ and Kala Kato upheavals that affected some northern states in July and December 2009 respectively.

\section{Conclusion}

Religious elites have significant contributions to make in the conception and execution of development programmes in developing countries like Nigeria. The Nigerian government acknowledges the enormity of the task of universal access to good quality education at the basic level, and knows that its execution would have to be in partnership with all levels of civil society. But beyond this polity rhetoric, it has not put in place mechanisms to mobilise and engage the potential contributions of communities and groups in the task of educational development. In particular, the government has displayed a pathetic inability to constructively engage with and regulate the participation of the Islamic religious elite and groups in the provision of education. On the contrary, a growing sense of isolation in Islamic schools has enabled 
the religious elite to consolidate their control over curricula content and management structures in these schools in worrying ways. This paper has explored the various dimensions of the ulama's engagement with the Nigerian state in the provision of education and their possible impact on educational development in Northern Nigeria and the pursuit of national unity.

\section{BIBLIOGRAPHY}

ABD-EL-KHALIK, F., BOYLE, H. \& PIER, D., 2006. Educational Quality in Islamic schools: Synopsis of Report No. 1: Nigeria, American Institutes for Research with Education Development Centre, Inc. (EDC) under the Educational Quality Improvement Programme (EQUIP) of the United States Agency for International Development (USAID).

ABDULRAHMAN, A.M. \& CANHAM, P., 1978. The Ink of the Scholar: Islamic Tradition of Education in Nigeria, Lagos, Macmillan.

ABERNETHY, D.B., 1969. The Political Dilemma of Popular Education, California, Stanford University Press.

ADEKOLA, O.A., 2007. Language, Literacy and Learning in Primary Schools: Implications for Teacher Development Programs in Nigeria, Washington, DC, The World Bank.

AIYEPEKU, T.F., 1989. 6-3-3-4 System of Education in Nigeria, Ibadan, NPS Educational Publishers Limited.

ARDO, G.V. \& JUNAID, 1990. Education in the Sokoto Caliphate: Continuity and Change, in A.M. Kani \& K.A. Gandi, State and Society in the Sokoto Caliphate, Sokoto, Nigeria, Usmanu Danfodiyo University: 291-299.

BALOGUN, S.A., 1980. History of Islam upto 1800, in O. Ikime, Groundwork of Nigerian History, Ibadan, Nigeria, Heinemann Educational Books (Nigeria) Ltd.

BANO, M., 2009. Engaged yet Disengaged: Islamic Schools and the State in Kano, Nigeria, Working Paper No. 29, Retrieved Online on 27 February 2010, from Religions and Development Research Programme, www.rad.bham.ac.uk.

BUGAJE, U.M., 1997. Some Reflections on the Development of Islamic Learning in Katsina State (1300-1800 AD), in I.A. Tsiga \& A.U. Adamu, Islam and the History of Learning in Katsina, Ibadan, Nigeria, Spectrum Books Limited: 77 -87.

CLARKE, P.B., 1982. West Africa and Islam, London, Edward Arnold (Publishers) Ltd.

DANFULANI, U.H.D., 2009. Popular Religiosities, Corporate Faiths and the Impact of Globalization on the Religious Landscape in Contemporary Nigeria, University of Jos Inaugural Lecture Series No. 39, December 4

DEBIEL, T., \& LAMBACH, D., 2010. Global Governance as Self-Deception: How the Western Statebuilding Project Neglects Local Politics, in M. Brzoska \& A. Kohn, Overcoming Armed Violence in a Complex World: Essays in Honour of Herbert Wulf, Budrich UniPress: 163-184.

DUDLEY, B.J., 1968. Parties and Politics in Northern Nigeria. London, Frank Cass. 
FAFUNWA, A.B., 1991. History of Education in Nigeria, Ibadan, NPS Educational Publishers Limited.

FEDERAL MINISTRY OF EDUCATION, 2005. Education Sector Status Report: A Condensed Version. Abuja, Federal Ministry of Education.

FEDERAL MINISTRY OF EDUCATION, 2009. Roadmap for the Nigerian Education Sector, Abuja, Federal Ministry of Education.

FEDERAL GOVERNMENT OF NIGERIA/UNITED NATIONS CHILDREN FUND, 1999. Non-Formal Education Curriculum for Qur'anic Schools, Abuja, FGN.

FEDERAL REPUBLIC OF NIGERIA, 2004. National Policy on Education, $4^{\text {th }}$ Edition, Yaba, NERDC Press. IBRAHIM, A.R., 2005. Muslim Educational Reform in South-western Nigeria, in Umar, B.A., Shehu, S. \& Malumfashi, M.U., Muslim Educational Reform Activities in Nigeria, Kano, Benchmark Publishers, 2005: 128-142.

KHALID, S., 1997. A Socio-Economic Study of the Transformation of Migrant Qur'anic Schools System (Almajiranci) in Sokoto Metropolis, 1970 - 1995, A PhD Thesis submitted to Dept. of Sociology, Bayero University Kano.

KHALID, S., 1999. State and Islamic Education in Northern Nigeria: an Historical Survey, Al-Nahda: A Journal of Islamic Heritage, Vol. 2, Nos. 1 \& 2, pp. 18-23.

LUBECK, P., 1999. Antinomies of Islamic Movements under Globalization, in Cohen, R., \& Rai, S.M., Global Social Movements, London/New Brunswick, The Athlone Press.

NATIONAL POPULATION COMMISSION (NIGERIA) \& ICF MACRO, 2009. Nigeria Demographic and Health Survey 2008, Abuja, Nigeria, National Population Commission and ICF Macro.

ODUMOSU, O., OLANIYI, R., \& ALONGE, S., 2010. Mapping the Activities of Faith-Based Organisations in Development in Nigeria, Working Paper No. 38, Retrieved Online on 27 February 2010, from Religions and Development Research Programme, www.rad.bham.ac.uk

OZIGI, A.O. \& L. OCHO, 1981. Education in Northern Nigeria, London and Boston, Allen \& Unwin. TAIWO, C.O., 1980. The Nigerian Education System: Past, Present \& Future, Lagos, Nelson Pitman Limited.

TIKUMAH, I.H., 2008. The Half-Scholar of Islam, Zaria, Ahmadu Bello University Press.

UMAR, M.S., 2001. Education and Islamic Trends in Northern Nigeria, Africa Today, Vol. 48, No. 2: $127-150$.

UMAR, M.S., 2003. Profiles of New Islamic Schools in Northern Nigeria, The Maghreb Review, Vol. 28, Nos. 2-3: 146-169.

UMAR, M.S., 2006. Islam and Colonialism: Intellectual Responses of Muslims of Northern Nigeria to British Colonial Rule, Leiden, Netherlands, Koninklijke Brill NV.

UNITED STATES AGENCY FOR INTERNATIONAL DEVELOPMENT, USAID, 2003a. Strengthening education in the Muslim world, Retrieved on 22November 2005 from www.gaelnet.designs.com/ publications/docs/strengtheningeducationinthemuslimworld.pdf

UNITED STATES AGENCY FOR INTERNATIONAL DEVELOPMENT, USAID, 2003b. Strategic Assessment of Social Sector Activities in Northern Nigeria, Retrieved on 22 June 2005 from www.usaid.gov/ng/ downloads/rfa/usaidnorthernassessmentreport1.pdf 


\section{NOTES}

1. 'Ulama' is the Arabic word for Islamic scholars (plural). The Hausa equivalent is malammai (plural) or malam (singular). The ulama establishment among the Hausa people is strongly maledominated.

2. This paper is part of an ongoing research work for a $\mathrm{PhD}$ in Curriculum Theory at the University of Jos, Nigeria being undertaken by the author with a fellowship grant from the American Council of Learned Societies, ACLS, New York.

3. I thank Dr. Ibrahim Hassan (Dept. of Religious Studies, University of Jos, Nigeria) for making available to me data he collected for an ACLS-sponsored study on "The Thoughts of the Fodio's on Development".

4. Prior to 1967, the Northern Region exercised administrative control over all of northern Nigeria. The number of semi-autonomous administrative units or states has risen from 12 in 1967 to 36 today.

5. Nigeria operates a 6-3-3-4 system of education: 6 years of primary education, 3 years of Junior Secondary School (JSS), 3 years of Senior Secondary Schools (SSS), and 4 years of University (or other types of tertiary) education. However, with the provisions of the UBE Act of 2004, the 6 years of primary education and the 3 years of JSS constitute 9 years of free, universal and compulsory basic education.

6. NCE is the official minimum teaching qualification in Nigeria.

7. Boko-Haram, a Hausa expression meaning 'western education is sinful', was the name given to a religious group led by an Islamic cleric, Mohammed Yusuf, that sought the forceful imposition of Shariah Islamic Law and a dismantling of state structures across some Northern Nigerian states (Bauchi, Borno \& Kano).

8. Kala Kato is a Hausa expression describing religious teachings propagated by some Islamic clerics or groups that lack any legitimacy from divine sources of Islam (the Quran, or Hadith, recorded the sayings and deeds of the Prophet Muhammad).

\section{ABSTRACTS}

Islamic schools in Nigeria have undergone transformations from a position of monopolistic control over spiritual knowledge to one of competition and subsequently struggle for survival as they encountered missionary and colonial incursions. The post-colonial state that emerged had to endure weakened Islamic schools which nonetheless retained legitimacy in the eyes of observant Muslims as culturally and religiously valued institutions. This paper describes a fluctuating pattern of mutual isolation, engagement and competition that characterise the relationship between the state, Islamic schools and an influential corps of Islamic clerics (Ulama) operating outside the spheres of state bureaucracy. Northern Nigeria, where these schools are prevalent, has endured a long list of developmental challenges including a low level of educational attainment which places it at a competitive disadvantage in its relationship with Southern Nigeria. The paper claims that although both the state and a section of the Ulama realise that a reform of Islamic schools is vital to the development of Northern Nigeria, a long period of mutual isolation and the weak position of Nigeria's educational bureaucracy have made the finding of a common operational framework difficult. A strong state-driven education 
delivery mechanism is what Nigeria needs to control the unregulated growth of different brands of Islamic schools from compounding its many developmental challenges.

Les écoles islamiques au Nigeria ont subi des transformations allant d'une position de contrôle monopolistique sur le savoir spirituel à une position de compétition, puis de lutte pour la survie face aux incursions missionnaires et coloniales. Par la suite l'État postcolonial émergeant s'est confronté à des écoles islamiques affaiblies mais conservant toutefois une certaine légitimité. Cet article montre que les relations entre État, écoles islamiques et ulamas opérant en dehors de la bureaucratie, fluctuent entre engagement, compétition et distanciation mutuelle. Au Nigeria du Nord, où ces écoles sont dominantes et où les défis pour le développement sont nombreux, le niveau d'instruction reste bas, ce qui place cette région en situation de relative faiblesse vis-àvis du Nigeria du Sud. L'article met en évidence qu'en dépit de leur volonté de réformer le système éducatif islamique l'État et les Ulamas peinent à trouver un cadre de travail commun. L'État nigérian parvient difficilement à contrôler la croissance irrégulée des écoles islamiques. 